Volume: 07, Issue: 06 "November-December 2021"

\title{
EVALUATION OF DIFFERENT SOURCES OF NITROGEN IN COVERAGE IN CORN SECOND CROP
}

\author{
${ }^{1 *}$ Pedro Henrique Dias Júnior, ${ }^{2}$ Kleso Silva Franco Júnior, ${ }^{3}$ Giselle Prado Brigante \\ ${ }^{1}$ Graduando do curso de Agronomia, CESEP, Machado MG, Brazil. \\ ${ }^{2}$ Department of Fitotecnia, CESEP, Machado MG, Brazil \\ ORCiD: 0000-0002-6807-8889 \\ ${ }^{3}$ Department of Fitotecnia, CESEP, Machado MG, Brazil \\ ORCiD: 0000-0002-0952-0075 \\ *Corresponding author
}

DOI: https://doi.org/10.51193/IJAER.2021.7605

Received: 24 Nov. 2021 / Accepted: 02 Dec. 2021 / Published: 03 Dec. 2021

\begin{abstract}
The cultivation of off-season corn in Brazil is expressive, mainly because the cultivation of soybeans in the first crop has been traditionalized and conditioning rotation with corn in the second crop. Nitrogen $(\mathrm{N})$ is one of the most required and important nutrients for good maize crop development. Nitrogen fertilization is, without a doubt, one of the fundamental management operations for success and yields. This work was carried out aiming to evaluate the effect of different $\mathrm{N}$ sources in the off-season corn crop. The experiment was carried out on a farm in the city of Paraguaçu, Minas Gerais, in the off-season of the agricultural year 2020/2021. The treatments constituted different sources of $\mathrm{N}$, being they: the control (without addition of $\mathrm{N}$ ). $\mathrm{T} 2$ 930g Polyblen 30-00-11 (0.279 kg/N), T3 607g 46\% N urea $(0.280 \mathrm{~kg} / \mathrm{N}), \mathrm{T} 41.330 \mathrm{~g} 21 \% \mathrm{~N}$ ammonium sulfate $(0.279 \mathrm{~kg} / \mathrm{N}), \mathrm{T} 5850 \mathrm{~g}$ of ammonium nitrate $33 \% \mathrm{~N}(0.280 \mathrm{~kg} / \mathrm{N}$, and T61.400g of polyblen $20-00-11(0.279 \mathrm{~kg} / \mathrm{N})$. The experimental delineation was in randomized blocks with six treatments and four replications. corn was harvested manually as soon as it reached the maturation stage, then dry mass and green mass of the aerial part were evaluated. control without any addition of $\mathrm{N}$ provided the best results, it is noteworthy that during the period of execution of the research, the climatic conditions in the region were quite adverse, with irregular rainfall and high temperatures;
\end{abstract}


Keywords: Safrinha, Grains, Nitrogen, Fertilization.

\section{INTRODUCTION}

Corn (Zea mays L.) is among the main cereals produced in Brazil and in the world, with a prominent position from a social and economic point of view.

The corn crop needs favorable climatic conditions to reach its maximum production, in addition to an adequate balance of soil nutrients. Among the main nutrients required by the plant, nitrogen $(\mathrm{N})$ is extremely important for its good development and production excellence, and is greatly influenced by environmental conditions and management practices.

In fertilizer supply, the $\mathrm{N}$ element in the crop does not fully absorb the applied $\mathrm{N}$, a situation attributed to the various loss processes that occur in the soil-plant-atmosphere system, such as leaching, volatilization and denitrification.

The efficiency of these fertilizers in reducing $\mathrm{N}$ losses, as well as their agronomic efficiency and their impact on corn grain yield, is highly dependent on soil and climate conditions and management practices.

Specifically in the off-season, we emphasize that one of the most limiting aspects to the productivity of the corn crop is the water deficit, which can occur in up to half of the lost productivity.

A ureia é a fonte de fertilizante a base de $\mathrm{N}$ mais utilizada na agricultura, porém, principalmente por ser uma fonte concentrada, porém sujeita a perdas por a volatilização na forma de amônia.

Broadly, an attenuated knowledge about the sources and release of $\mathrm{N}$ provided by nitrogen fertilizers allows for a reduction in applied doses and greater efficiency in the use of the nutrient, minimizing environmental impacts, reducing losses due to leaching and volatilization, and increasing productivity, since the plant will have the element available to the extent of its need. The use of $\mathrm{N}$ sources that allow the best use has been the subject of numerous researches, aiming at improving productivity and minimizing environmental impacts

For this purpose, this work aimed to evaluate the effect of different nitrogen sources applied to corn second crop coverage.

\section{MATERIALS AND METHODS}

The research was carried out from February to June 2021 at Sitio Rabicho, located in the city of Paraguaçu, in the south of the State of Minas Gerais. Located at 810 meters of altitude, with 
latitude: $21^{\circ} 33^{\prime} 22^{\prime \prime}$ South, and longitude: $45^{\circ} 44^{\prime} 22^{\prime \prime}$ West. It has a warm and temperate climate and in winter there is much less rainfall than in summer. According to Köppen and Geiger, the climate classification is Cwa, that is, climate with summer rain and hot summer (EXPOSTI, 2013). The average annual temperature in the municipality is $20.5{ }^{\circ} \mathrm{C}$, and average annual rainfall is $1461 \mathrm{~mm}$ (CLIMATE, 2021).

Being the month with the driest characteristic, July, which presents an average of $25 \mathrm{~mm}$ of precipitation. According to data from Clima Tempo, most of the precipitation occurs in the month of December, with an average of $270 \mathrm{~mm}$ (CLIMATE, 2021).

January is the hottest month of the year, with an average temperature of $23.3{ }^{\circ} \mathrm{C}$, while the average temperature in June is $16.6{ }^{\circ} \mathrm{C}$, being the lowest average of the year (table 1). (CLIMATE, 2021).

Table 1: Average, minimum and maximum temperature in the municipality of Paraguaçu/MG in 2020 [2]

\begin{tabular}{|c|c|c|c|c|c|c|c|c|c|c|c|c|}
\hline & Janeiro & Fevereiro & Março & Abril & Maio & Junho & Julho & Agosto & Setembro & Outubro & Novembro & Dezembro \\
\hline Temperatura média $\left({ }^{\circ} \mathrm{C}\right)$ & 23.3 & 23.2 & 21.7 & 20.3 & 17.5 & 16.6 & 17.3 & 19.2 & 20.7 & 21.8 & 22.3 & 21.8 \\
\hline Temperatura mínima $\left({ }^{\circ} \mathrm{C}\right)$ & 17.6 & 17.4 & 15.6 & 14.1 & 10.3 & 9 & 9.5 & 11.4 & 13.8 & 15.6 & 16.7 & 15.8 \\
\hline Temperatura máxima $\left({ }^{\circ} \mathrm{C}\right)$ & 29.1 & 28 & 27.9 & 26.5 & 24.8 & 24.3 & 25.2 & 27 & 27.7 & 28.1 & 28 & 27.7 \\
\hline Chuva (mm) & 255 & 199 & 164 & 69 & 47 & 29 & 25 & 28 & 67 & 132 & 178 & 270 \\
\hline
\end{tabular}

The soil in the experiment area has a dark red color and is classified as clayey with $35 \%$ clay, being a red-yellow oxisol. The soil analysis carried out to implement the research showed the following chemical characteristics in the 0-0.20 m layer: $\mathrm{pH}(\mathrm{H} 2 \mathrm{O}): 5.89$; $\mathrm{Al}+3, \mathrm{Ca}+2$ and $\mathrm{Mg}+2$ 2.81 and $0.96 \mathrm{cmol} \mathrm{dm}-3$, respectively; $\mathrm{P}($ Mehlich-1) and $\mathrm{K}+$ (Mehlich-1): 11.0 and $70.0 \mathrm{mg} \mathrm{dm}-$ 3, respectively; organic matter (Walkley Black): 1.87 dag kg-1; CTC (pH 7.0) (T): $6.89 \mathrm{cmol}$ $\mathrm{dm}-3 ; \mathrm{V}: 58.9 \%$. The experimental area had a history of 4 years of cultivation of maize on maize, before the installation of the experiment the soil preparation was carried out in a conventional way through a heavy harrow and a light harrow. The fertilization was carried out based on the parameters of the 5th approximation, being calculated according to the characteristics presented by the soil analysis $(0-0.20 \mathrm{~m})$, the application of fertilizers was done in the sowing furrow 300 $\mathrm{kg}$ ha-1 of the formula $08-24-12+\mathrm{Zn}$.

Sowing was carried out on February 28, 2021, with a Jumil model 2680PD planter with 4 rows spacing $70 \mathrm{~cm}$ between rows and 4.2 seeds per meter, totaling 60 thousand plants ha-1, the genetic material used was the Feroz hybrid vip 3 Syngenta. 
International Journal of Agriculture and Environmental Research

ISSN: 2455-6939

Volume: 07, Issue: 06 "November-December 2021"

The experiment was installed in a randomized block design with 6 (six) treatments and 4 (four) repetitions, totaling 24 (twenty four) experimental plots. Five different sources of nitrogen $(\mathrm{N})$ applied in topdressing were used, in addition to 1 control distributed as follows:

$$
\begin{aligned}
& \mathrm{T} 1=\text { Control }(\text { without adding N), } \\
& \mathrm{T} 2=333 \mathrm{~kg} / \mathrm{ha}^{-1} \text { of Polyblen 30-00-11, } \\
& \mathrm{T} 3=217 \mathrm{~kg} / \mathrm{ha}^{-1} \text { Urea } 46 \% \mathrm{~N}, \\
& \mathrm{~T} 4=476 \mathrm{~kg} / \mathrm{ha}^{-1} \text { Ammonium Sulfate } 21 \% \mathrm{~N}, \\
& \mathrm{~T} 5=303 \mathrm{~kg} / \mathrm{ha}^{-1} \text { Ammonium Nitrate } 33 \% \mathrm{~N}, \\
& \mathrm{~T} 6=500 \mathrm{~kg} / \mathrm{ha}^{-1} \text { Polyblen } 20-00-11
\end{aligned}
$$

Following the standardized dosages of $100 \mathrm{~kg} \mathrm{ha}^{-1}$ of $\mathrm{N}$ in coverage for each source.

The application was performed 20 days after the emergency (DAE) and the other elements were adjusted so that they were all provided equally in all treatments, only varying the source in relation to $\mathrm{N}$.

With 134 DAE from the plants, the material was manually harvested for evaluation, due to the water deficit faced during the experiment; the collection of samples had to be anticipated. Twenty central plants were collected from each plot; they were stored in bags identified with each treatment and repetition. The process to crush this material was used in a 3 knives ensiladery with a $3 \mathrm{hp}$ electric motor and soon after this material was weighed and separated 300 grams where it was taken to a microwave oven to carry out the water loss of the material.

According to Oliveira et al. (2015) dry matter can be measured using a microwave oven, a technique that was used in this experiment. The plant sample was placed in the microwave together with a glass of water, after 3 minutes at full power it was removed and after cooling the sample was mixed and placed again in the microwave for 2 minutes, and this process was repeated with 1 minute and then with 30 seconds of oven, and the repetition was necessary with the last time until the sample weight was the same for three consecutive weighings. The final value was given as the result of the formula: Dry matter $(\%)=(100 \mathrm{x}$ Final Weight $) \div$ Initial Weight.

The following variables were evaluated: green mass weight (ton ha-1) and dry mass weight of the aerial part (ton ha-1).

The results were subjected to analysis of variance and comparison of means made by the ScottKnott test, at 5\% probability, both using the SISVAR ${ }^{\circledR}$ software (FERREIRA, 2014). 


\section{RESULTS AND DISCUSSION}

After manually harvesting the corn plants, in June/2021 they were subjected to evaluation of green mass weight and dry mass, as shown in table 2.

Table 2: Green and dry mass weight of the aerial part of the maize (ton/ha-1), submitted to different sources of $N$ coverage

\begin{tabular}{ccc}
\hline $\begin{array}{c}\text { Green Mass Dry Mass } \\
\text { Treatment }\end{array}$ & $\begin{array}{c}\text { Green Mass Dry Mass } \\
\text { Treatment }\end{array}$ & $\begin{array}{c}\text { Green Mass Dry Mass } \\
\text { Treatment }\end{array}$ \\
\hline 1 -Control & $3.870 \mathrm{~A}$ & $2.805 \mathrm{~A}$ \\
2 - Polyblen 30-00-10 & $3.153 \mathrm{~B}$ & $2.370 \mathrm{~B}$ \\
3 - Ureia 46\% & $3.890 \mathrm{~A}$ & $2.868 \mathrm{~A}$ \\
4 - Sulfato de Amônio21\% & $3.465 \mathrm{~B}$ & $2.420 \mathrm{~B}$ \\
$\mathbf{5}$ - Nitrato de Amônio 33\% & $3.063 \mathrm{~B}$ & $2.280 \mathrm{~B}$ \\
6 - Polyblen 20-00-11 & $3.920 \mathrm{~A}$ & $2.772 \mathrm{~A}$ \\
\hline CV (\%) & 6.03 & 6.03 \\
\hline
\end{tabular}

*Means followed by different letters in the column differ statistically by the Knott Scoot test at $5 \%$ probability

Treatments 1, 3 and 6 showed statistical differences from the other treatments in the production of green mass and dry mass.

Although corn is one of the options for cultivation in the second crop in the region and in the country, it has even been showing a growing increase in cultivated area in recent years, however, we cannot forget the risks arising from adverse weather conditions quite common at this time.

Among the existing climatic factors, the ones that stand out in the corn crop are: solar radiation, temperature and precipitation. These factors are directly related to plant growth and development, and their action varies with the plant's phenological stage, so each stage has different tolerable levels (MALDANER, et al., 2014).

According to CONAB data, (YEAR) the second crop corn planting has been occupying areas larger than those destined for summer corn cultivation, its production and planted area is twice the size when compared to the summer crop.

It can be observed that the results obtained in this experiment were not as satisfactory, due to adverse climatic conditions during cultivation, such as high temperatures and lack of rain, which negatively influenced the development of the crop, as shown in tables 3 and 4. 
International Journal of Agriculture and Environmental Research

ISSN: 2455-6939

Volume: 07, Issue: 06 "November-December 2021"

Table 3: Weather data from February to July/2021 in Paraguaçu MG

\begin{tabular}{ccccccc}
\hline & February & March & April & May & June & July \\
\hline $\mathbf{2 0 2 1}$ & $261 \mathrm{~mm}$ & $103 \mathrm{~mm}$ & $27 \mathrm{~mm}$ & $38 \mathrm{~mm}$ & $52 \mathrm{~mm}$ & $1 \mathrm{~mm}$ \\
\hline
\end{tabular}

Table 4: Meteorological and historical data on rainfall distribution in the city of Alfenas/MG (COOXUPÉ)

\begin{tabular}{ccccccc}
\hline & February & March & April & May & June & July \\
\hline $\mathbf{2 0 2 0}$ & $165 \mathrm{~mm}$ & $121,4 \mathrm{~mm}$ & $21,4 \mathrm{~mm}$ & $8 \mathrm{~mm}$ & $21,6 \mathrm{~mm}$ & $0 \mathrm{~mm}$ \\
$\mathbf{2 0 1 9}$ & $167,4 \mathrm{~mm}$ & $153,4 \mathrm{~mm}$ & $111,4 \mathrm{~mm}$ & $92,2 \mathrm{~mm}$ & $4,4 \mathrm{~mm}$ & $7 \mathrm{~mm}$ \\
\hline
\end{tabular}

Source: http://sismet.cooxupe.com.br:9000/

According to meteorological records, rainfall distribution during the growing season was below average.

Compared to previous years, although February and June/2021 had more rainfall, the months of March, April and July were much lower compared to 2019, as shown in table 4.

According to Conab, rains were below the historical average, causing losses in the corn second crop, still associated with the delay in planting and harvesting soybeans, which also affected the second crop planting window (CONAB, 2021).

Normally, the water deficit is more accentuated the later the corn sowing date, since the lack of moisture in the soil hinders the absorption of nutrients by the plant (SIMÃO et al., 2018).

Simão and collaborators (2018) concluded that sowing in January favors productivity by reconciling better rainfall distribution at the end of the vegetative and reproductive phases.

Andrade (2020) explains that the lack of water can compromise three stages of maize development, namely the beginning of flowering, the pollination period and grain filling.

Some sources point out that maize maximum productivity occurs when water consumption throughout the cycle is between 500 and $800 \mathrm{~mm}$, however, the crop requires a minimum of 350 to $500 \mathrm{~mm}$ for it to produce without the need for irrigation. (ANDRADE, 2020).

According to Magalhães and Durães (2006), the water consumption of corn is around $600 \mathrm{~mm}$, and it can be cultivated in a range between 300 and $5,000 \mathrm{~mm}$. 
International Journal of Agriculture and Environmental Research

ISSN: 2455-6939

Volume: 07, Issue: 06 "November-December 2021"

The main factor influencing the success of the crop is solar radiation, which is why the climate can favor or hinder the producer. The off-season, target of this work, was affected by high temperatures, especially in February and March, exceeding $30^{\circ} \mathrm{C}$. Compared to the last two years, there is a noticeable increase in temperature during the planting months

Fancelli \& Dourado Neto (2000), in a study on corn production, shows that temperatures below $10^{\circ} \mathrm{C}$ and above $40^{\circ} \mathrm{C}$ : can reduce the percentage of germination; between $25^{\circ} \mathrm{C}$ and $30^{\circ} \mathrm{C}$ would be the ideal temperature; above $26^{\circ} \mathrm{C}$ : accelerate flowering; below $15.5^{\circ} \mathrm{C}$ : delay flowering; and above $21^{\circ} \mathrm{C}$ (within 60 days after sowing): each degree can accelerate flowering (maximum advance of three days).

Rehagro (2018), in its blog, corroborating the data, published that the ideal temperature conditions for corn in the germination phase would be between 25 and $30^{\circ}$, in the emergency phase, flowering, from 24 to $30^{\circ}$, and the temperature daily average of $21^{\circ}$ leads to a higher grain yield. Bringing information also that the occurrence of cloudy period, water deficit, reduction of leaf area due to pests and diseases and nutritional imbalance, will considerably reduce the dry matter accumulation rate in the grains, reducing their weight and productivity.

Solar radiation is totally linked to direct mass production in maize, so the ratio of accumulated dry matter mass and the radiation intercepted by the plant over a period of time, gives the efficiency in mass production of the plant (MALDANER, et al. ., 2014).

The positive result of corn second crop is related to the sowing time. For this reason, in an article published by MyFarm (2021) it is recommended to plant earlier, after harvesting the summer crop, as it increases the chances of obtaining a good off-season corn crop. Thus, the risks caused by reduced air temperature in winter and availability of water in the ground are reduced.

\section{CONCLUSION}

It is concluded that the sources of $\mathrm{N}$, Urea 46\%, Polyblen 20-00-11, and the control (without any addition of $\mathrm{N}$ ) were the most efficient in covering in the off-season corn crop, under the conditions of the experiment that had unforeseen environmental such as water deficit and high temperatures.

\section{REFERENCES}

[1] EXPOSTI, K. D. Classificação climática de Köppen-Geiger. Info Escola. 2013. Disponívelem: <https://www.infoescola.com/geografia/classificacao-climatica-dekoppen-geiger/>Acessoem:17jun.2021. 
[2] CLIMATE. Paraguaçu Clima. Disponível em: <https://pt.climate-data.org/america-dosul/brasil/minas-gerais/paraguacu-176430/> Acessoem:17jun.2021.

[3] FERREIRA, D. F. Sisvar: a computer statistical analysis system. Ciência eAgrotecnologia,v.35,n.6,p.1039-1042,2014.

[4] MALDANER, L. J. Et al. Exigênciaagro climática da cultura do milho (Zea mays). Revista Brasileira de Energias Renováveis, v. 3, p. 13-23, 2014. Disponívelem: < https://core.ac.uk/download/pdf/328077632.pdf>Acessoem: 22 nov. 2021.

[5] CONAB. Portalde Informaçõesagrícolas: Safra-Sériehistóricadosgrãos. Disponível em: $<$ https://portaldeinformacoes.conab.gov.br/safra-serie-historicagraos.html>Acessoem:29abr.2021.

[6] _ Boletim da Safra de Grãos: $8^{\circ}$ levantamento - Safra 2020/21. Disponível em: <https://www.conab.gov.br/info-agro/safras/graos/boletim-da-safra-degraos/item/download/37061_9f96937bef1ba89e8b223cc73dbb2475> Acesso em: 22 nov. 2021.

[7] SIMÃO, E. P.; RESENDE, A.V.; NETO, M. M. G.; BORGHI, E.; VANIN, Á. Resposta do milhosafrinha à adubaçãoemduasépocas de semeadura. Revista Brasileira de Milho e Sorgo, v.17, n.1, p.76-90. 2018. Disponívelem: < https://www.alice.cnptia.embrapa.br/handle/doc/1091864> Acessoem: 22 nov. 2021.

[8] ANDRADE, C. Por que o clima é tão importante para o Milho Safrinha? Nutrição das Safras. 2020. Disponível em: <https://nutricaodesafras.com.br/impacto-do-clima-nomilho/> Acesso em: 22 nov. 2021.

[9] MAGAlhães, P. C.; DURÃES, E. O. M. Fisiologia da produção de milho. EMBRAPA (Circular Técnica 76). Sete Lagoas, 2006, 10 p. Disponível em: <http://www.cnpms.embrapa.br/publicacoes/publica/2006/circular/Circ_76.pdf> Acesso em: 22 nov. 2021.

[10] FANCELLI, A. L.; DOURADO NETO, D. Produção de milho. Guaíba: Agropecuária, 2000. 360p.

[11] REHAGRO BLOG. Clima e produtividade do milho: efeitos das variaçõesclimáticas no rendimento de grãos. 2018. Disponívelem: < https://rehagro.com.br/blog/clima-eprodutividade-do-milho/>Acessoem: 22 nov 2021.

[12] MYFARM. Millhosafrinha: saibacomogarantiruma boa segundasafra de verão. 2021. Disponívelem: < https://www.myfarm.com.br/milho-safrinha/>Acessoem: 22 nov. 2021. 